\title{
METHANE ADSORPTION PERFORMANCE OF THE PALM KERNEL SHELL-DERIVED CARBON MATERIAL ACTIVATED USING $\mathrm{CO}_{2-}$ STEAM SEQUENTIAL COMBINATION
}

\author{
(Prestasi Penjerapan Gas Metana oleh Karbon Teraktif Isirong Kelapa Sawit dengan \\ Menggunakan Gabungan $\mathrm{CO}_{2}$-Stim Secara Turutan)
}

\author{
Mohd Saufi Md Zaini and Syed Shatir A. Syed Hassan* \\ Faculty of Chemical Engineering, \\ Universiti Teknologi MARA, 40450 Shah Alam, Selangor, Malaysia
}

*Corresponding author: shatir@salam.uitm.edu.my

\begin{abstract}
A study was conducted to prepare activated carbon from $\mathrm{ZnCl}_{2}$-treated oil palm kernel shell using the sequential combination of carbon dioxide and steam $\left(\mathrm{CO}_{2}+\right.$ steam) as activated agent. The development of pores of activated carbon and methane adsorption on the prepared activated carbon were investigated. The results show that the sequential combination of $\mathrm{CO}_{2}$ and steam was a good combination producing activated carbon with high total pore volume of $1.0 \mathrm{~cm}^{3} / \mathrm{g}$ and BET surface area of $1548.0 \mathrm{~m}^{2} / \mathrm{g}$. The resultant activated carbon contained microporous and mesoporous structure with a nearly balance volume percentage. The highest methane uptake in this study was $145.89 \mathrm{~V} / \mathrm{V}$ at 10 bar and ambient temperature.
\end{abstract}

Keywords: activated carbon, palm kernel shell, methane adsorption, porosity development

\section{Abstrak}

Satu kajian telah dijalankan bagi menyediakan karbon teraktif daripada isirong kelapa sawit yang dirawat bersama $\mathrm{ZnCl}_{2}$ dengan menggunakan agen pengaktifan karbon dioksida dan stim secara berturutan. Dalam kajian ini, pembangunan liang pada karbon teraktif dan penjerapan gas metana telah dikaji. Hasil dari kajian ini menunjukkan bahawa kombinasi secara urutan bagi gas karbon dioksida dan stim merupakan kombinasi agen pengakifan yang baik dan menghasilkan karbon teraktif yang mempunyai jumlah isipadu liang yang tinggi iaitu $1.0 \mathrm{~cm}^{3} / \mathrm{g}$ dan luas kawasan BET sebanyak $1548.0 \mathrm{~m}^{2} / \mathrm{g}$. Karbon teraktif yang terhasil juga mempunyai kandungan liang mikro dan liang meso yang hampir seimbang. Hasil kajian ini, penjerapan gas metana yang tertinggi adalah $145.89 \mathrm{~V} / \mathrm{V}$ pada $10 \mathrm{bar}$ dan suhu ambien.

Kata kunci : karbon teraktif, isirong kelapa sawit, penjerapan gas metana, pembangunan liang

\section{Introduction}

A sustainable energy supply and environmental protection are the challenges faced by the world presently. Conserving the sustainable energy is vital in order to ensure the security and the consistency of supply and the diversification of the various energy resources. The search for alternative fuel for vehicles has been actively pursued nowadays due to the issue of sustainability, energy and oil market crisis, and the increased awareness of environmental protection

Methane gas is a promising alternative fuel. It is a clean gas and can be found through various resources such as lake, swamp, landfill and also from fossil fuel. However because of its very low energy density, storing large amounts of methane in a limited volume is very challenging for its application like gas-powered vehicles. A new revolution of natural gas storage technology has been developed through adsorption in porous materials 


\section{Mohd Saufi \& Syed Shatir: METHANE ADSORPTION PERFORMANCE OF THE PALM KERNEL SHELL-DERIVED CARBON MATERIAL ACTIVATED USING $\mathrm{CO}_{2}$-STEAM SEQUENTIAL COMBINATION}

(activated carbon) which known as adsorbed natural gas (ANG). By using this technique, methane gas can be stored in the same amount as conventional tank but at a lower pressure. The activated carbon provides "extra room" for storing methane gas. The force exerted by the carbon atom inside the pores attract a lot of methane gas molecules into the pores, thus the amount of the bulk of gas will reduce. As a result, the pressure of tank can be kept as low as possible while maintaining high density of methane in the pores.

Extensive studies have been performed to enhance the ability of adsorbing methane gas through activated carbon produced from low cost agriculture waste precursors [1-3]. Production of the most suitable activated carbon for the gas adsorption application usually requires consideration of various factors such as chemical agent, impregnation ratio, activation temperature, and activation time [4]. One of the crucial factor contributing to the pore development of activated carbon is activation agents [5]. Different agents may influence differently in the properties, the activation rate and the yield of carbon material.

There are two main steps in producing activated carbon: i) the carbonisation of raw precursors in the absence of oxidising gas and ii) the activation of carbonisation product (char) using activation agent (physical, chemical or combination of both). Physical activation is widely used and can be applied to all raw materials. Generally, the precursors will undergo carbonisation process in the presence of inert gas at $500-800{ }^{\circ} \mathrm{C}$ followed by the activation by oxidising gas such as steam, $\mathrm{CO}_{2}$ or their mixture at $800-1100{ }^{\circ} \mathrm{C}$. During carbonisation, the precursors undergo three main stages: i) the elimination of water, ii) the primary pyrolysis (i.e. thermal decomposition of carbonaceous materials to form basic char structure, light gases and tar) and iii) the consolidation of char structure [6]. In the activation step, some carbons are eliminated by the activation agent to form gases via reactions (1) or (2), thus develop the porosity in the carbonised materials

$\mathrm{CO}_{2}$ activation

$$
\mathrm{C}+\mathrm{CO}_{2}=2 \mathrm{CO}
$$

Steam activation

$$
\mathrm{C}+\mathrm{H}_{2} \mathrm{O}=\mathrm{CO}+\mathrm{H}_{2}
$$

Although large amount of researches have been conducted with steam, $\mathrm{CO}_{2}$ or their simultaneous combination (i.e. mixture) as activating agent for different types of carbonaceous material $[5,7,8]$, very few of the previous works has addressed the effect of $\mathrm{CO}_{2}$-steam activation sequences on the pore development for methane adsorption application. This study is therefore aimed in investigating the methane adsorption performance from palm kernel shell derived activated carbon using the sequential combination (as opposed to the usual simultaneous combination) of $\mathrm{CO}_{2}+$ steam activation. Our findings provide additional insight into developing an efficient activation procedure for producing high quality activated carbon for methane adsorption.

\section{Raw material preparation}

\section{Materials and Methods}

Oil palm kernel shells (PKS) were used as activated carbon precursors in this study. PKS were obtained from Sime Darby Research and Development Centre (R\&D) in Carey Island, Malaysia. PKS samples were washed with distilled water to remove dust and impurities. The washed PKS were sundried for 48 hours and further dried in an oven at $110{ }^{\circ} \mathrm{C}$ overnight to remove moisture and to preserve from biological degradation. The dried PKS were crushed and sieved to obtain particles sizes in the range of 0.5 to $1.0 \mathrm{~mm}$.

\section{Preparation of activated carbon}

Dried PKS with the mass of $110( \pm 0.1) \mathrm{g}$ were mixed into $220 \mathrm{~mL}$ solution ( $98 \%$ purity from Acros Organics) of $55 \%(\mathrm{w} / \mathrm{w})$ zinc chloride. The mixture was stirred by a magnetic stirrer in a beaker at $80{ }^{\circ} \mathrm{C}$ for 3 hours. The mixture was then dried in an oven at $110{ }^{\circ} \mathrm{C}$ until the PKS achieved complete dryness. Figure 1 shows the experimental setup for carbonisation and activation processes. The setup consists of a double layer stainless steel reactor. The treated-PKS was carbonised under nitrogen flow of $192 \mathrm{~cm}^{3} / \mathrm{min}$ until the temperature reached $900{ }^{\circ} \mathrm{C} . \mathrm{N}_{2}$ gas was then switched to $\mathrm{CO}_{2}$ and followed by steam sequentially for 2 hours. The activated carbon obtained was washed under stirring with $0.1 \mathrm{M}$ of hydrochloric acid for one hour and further washed with hot distilled water six times (30 minutes each) to remove the remaining chemicals. 


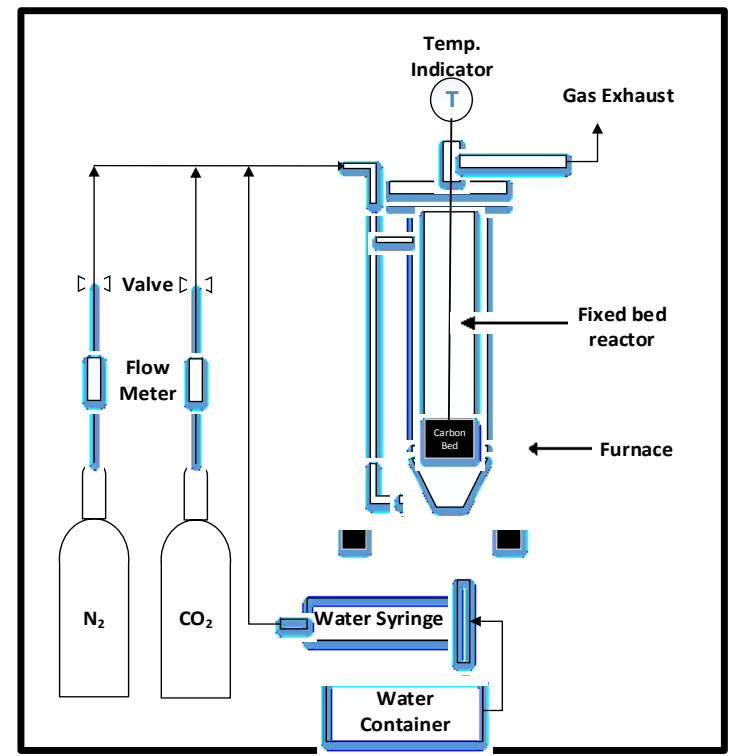

Figure 1. Schematic diagram of the preparation of activated carbon

\section{Methane adsorption by volumetric method}

An amount $20( \pm 0.1) \mathrm{g}$ of activated carbon sample was weighed and placed into high pressure stainless steel adsorbent cell and degassed for several hours to remove any impurity at room temperature. Schematic diagram of experimental set-up is shown in Figure 2. Two pressure transmitters model TPS20-G27F8-00 (range 0 - 20 $\mathrm{kg} / \mathrm{cm}^{3}$ with accuracy \pm 0.001$)$ manufactured by Murr Electronic were used to measure the pressure. The temperature condition of the experiment was within the range of $300( \pm 0.1) \mathrm{K}$ up to $303( \pm 0.1) \mathrm{K}$. Methane gas was injected using needle valve up to $10( \pm 0.001)$ bar continuously. The number of mol of methane uptake was determined from the mass balance by the application of ideal gas equation of states (3).

$$
n_{a d s}=\frac{1}{M_{w}}\left[\left(\frac{P_{r_{1}}}{Z_{r_{1}}}-\frac{P_{r_{2}}}{Z_{r_{2}}}\right) \frac{V_{g l}}{R T}-\left(\frac{P_{a d_{2}}}{Z_{a d_{2}}}-\frac{P_{a d_{1}}}{Z_{a d_{1}}}\right) \frac{V_{a d}}{R T}\right]
$$

where $M_{w}$ is molecular weight of methane gas, $V_{r}$ is volume of reference cell and $V_{a d}$ is volume of adsorption cell.

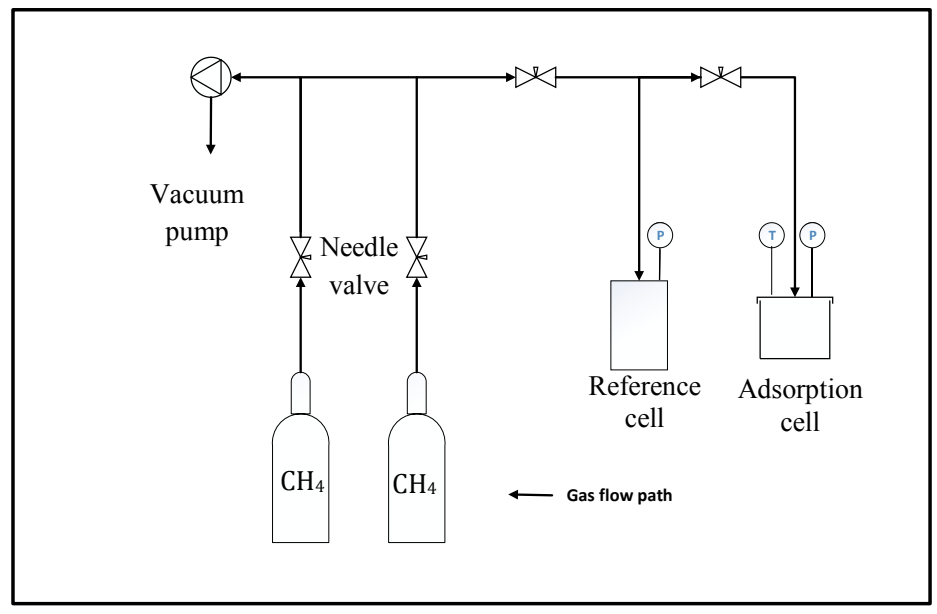

Figure 2. Schematic diagram of methane adsorption unit 


\section{Mohd Saufi \& Syed Shatir: METHANE ADSORPTION PERFORMANCE OF THE PALM KERNEL SHELL-DERIVED CARBON MATERIAL ACTIVATED USING $\mathrm{CO}_{2}$-STEAM SEQUENTIAL COMBINATION}

Proximate and ultimate analysis

\section{Results and Discussion}

Based on the proximate and ultimate analyses the volatile matter of the PKS is $62 \%$ and the carbon content of $48 \%$. Sufficient amount of volatile content is important, since the evolution of volatiles during carbonisation and activation processes results in making more porous structures in activated carbon [9]. The high carbon content contributes to structural strength of activated carbon [10]. After activation process (using steam $+\mathrm{CO}_{2}$ agents), the volatile content of PKS (activated carbon) decreased drastically from $62.15 \%$ to $13.8 \%$ whilst the fixed carbon increased from $34.85 \%$ to $69.59 \%$. This is because at high degree of activation the volatile were removed through thermal decomposition aided by activation agent $\left(\mathrm{CO}_{2}+\right.$ Steam $)$ leaving the residual elementary carbon atom (fixed carbon). Thus, it can be seen in Table 1 that the percentage of carbon (C) was also increased which subsequently caused in decrease to the other elements.

Table 1. Proximate and ultimate analysis of raw PKS and activated carbon PKS

\begin{tabular}{lcccccccc}
\hline Sample & & \multicolumn{3}{c}{ Proximate Analysis (wt. \%) } & \multicolumn{4}{c}{ Ultimate analysis (wt. \%) } \\
\hline & Moisture & Volatile Matter & Fixed carbon & Ash & C & H & N & O \\
\hline Raw PKS & 1.60 & 62.15 & 34.85 & 1.4 & 47.9 & 7.2 & 1.0 & 43.9 \\
AC PKS & 7.01 & 13.80 & 69.59 & 9.6 & 68.7 & 3.0 & 2.1 & 26.2 \\
\hline
\end{tabular}

\section{Characteristics of prepared activated carbon}

The activated carbon was characterised by $\mathrm{N}_{2}$ adsorption/ desorption, BET surface and pore size distribution analyses. Figure 3 shows the adsorption/desorption isotherm of nitrogen at $77 \mathrm{~K}$. It can be ascertained from the graph that the isotherm of activated carbon belongs to the Type IV of IUPAC classification [11] representing adsorption isotherm with hysteresis. The Type IV shape follows the same path as Type II at lower relative pressure. The sharp "knee" suggests that a considerable amount of micropores are present, and the slop of the plateau at high relative pressure is due to multilayer adsorption on non-microporous, i.e. mesoporous [12]. This indicates that the porous structures of the activated carbon are mainly microporous and mesoporous. According to Kundu et al. [13], intensive activation would increase the elimination of low molecular weight volatiles that causes development in pore. The use of $\mathrm{CO}_{2}$ changes the structure (especially the outer one) of char, leaving more active site to be used for steam to generate microporous structure at a faster rate. In addition, at high temperature $\left(900^{\circ} \mathrm{C}\right)$ the microporous structure was collapsed to result in the formation of mesoporous activated carbon.

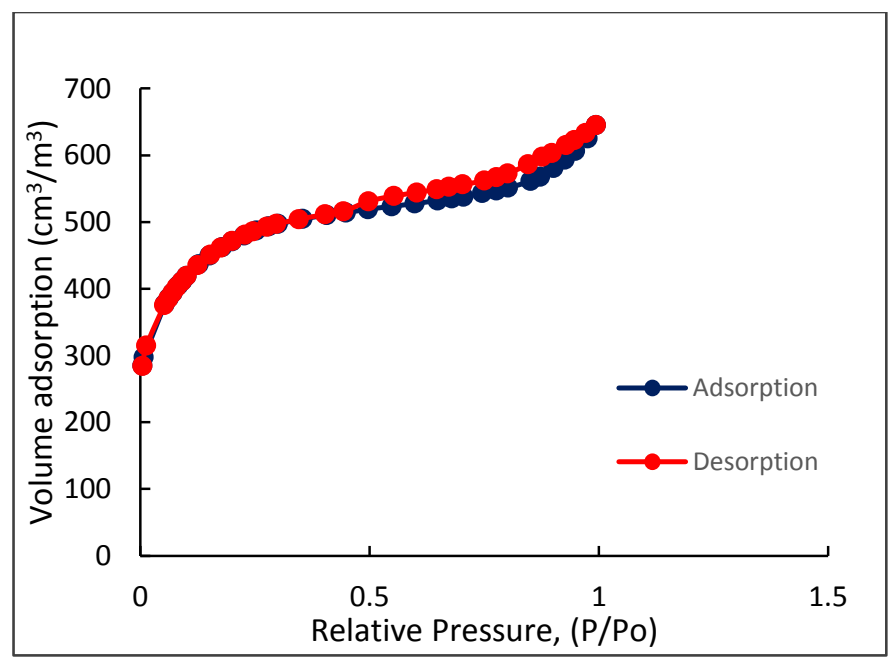

Figure 3. $\mathrm{N}_{2}$ adsorption on activated carbons produced at the optimum conditions 
From the nitrogen adsorption isotherm analysis, the BET surface area and total pore volume of the activated carbon were $1551 \mathrm{~m}^{2} / \mathrm{g}$ and $1.00 \mathrm{~cm}^{3} / \mathrm{g}$, respectively. According to Rodriguez-Reinoso et al., steam activation aids enhancement and continuously develops microporosity which would produce more selective attack on the carbon structure, while $\mathrm{CO}_{2}$ activation tends to enhance the size of micropores to produce more mesoporous and macroporous volume. Therefore, the combination using $\mathrm{CO}_{2}$ as the first agent and steam as the second agent is a good combination to improve the porosity since $\mathrm{CO}_{2}$ enlarges the existing pores allowing steam to penetrate deep into or inside porous structure and creates more new pores in the carbon, resulting in a higher surface area and pore volume. Furthermore, with $\mathrm{ZnCl}_{2}$ impregnation, the removal of the volatiles through the pore passage was not hindered since $\mathrm{ZnCl}_{2}$ acts as a dehydrating agent during activation that inhibit tar formation and other liquid clogging, thus increasing number of porosity [14].

Figure 4 illustrates the distribution of pore development by DFT analysis of nitrogen isotherm. Based on the graph, the observed peaks are in the range of 1 to $3 \mathrm{~nm}$, indicating that majority of pores are located within microporous and initial mesoporous range, thus it can be concluded that the result obtained is consistent with the $\mathrm{N}_{2}$ isotherm trend discussed above. The proportion of micropores $(58 \%)$ and mesopores $(42 \%)$ of the activated carbon in this study are nearly balance. It can be inferred that, at low degree of activation, the microporous structure was initially developed and it was progressively widens with increase in degree of activation.

\section{Methane adsorption}

The activated carbon prepared using combination of $\mathrm{CO}_{2}+$ steam underwent further analysis of methane adsorption. The activated carbons prepared from single activation of steam and $\mathrm{CO}_{2}$ were also prepared at the same conditions for comparative study. Figure 5 shows the methane uptake $(\mathrm{mol} / \mathrm{kg})$ of all the three activated carbons. The methane gas were charged continuously until the pressure reached 10 bar and measured at $293.15 K$. It can be seen clearly, methane uptake increases linearly with the pressure. The results agree well with a previous study by Arami-Niya et al. [15]. High amount of methane adsorption is expected when the adsorption has large surface area and high total pore volume. In this study, it is suggested that the porosity of activated carbon prepared using combination of $\mathrm{CO}_{2}+$ steam is well developed compared to other set of conditions. It is clearly shown in Table 2, the BET surface area and total pore volume are double the amount of other activated carbons. However higher percentage of microporous structure can be observed when using single activation agent.

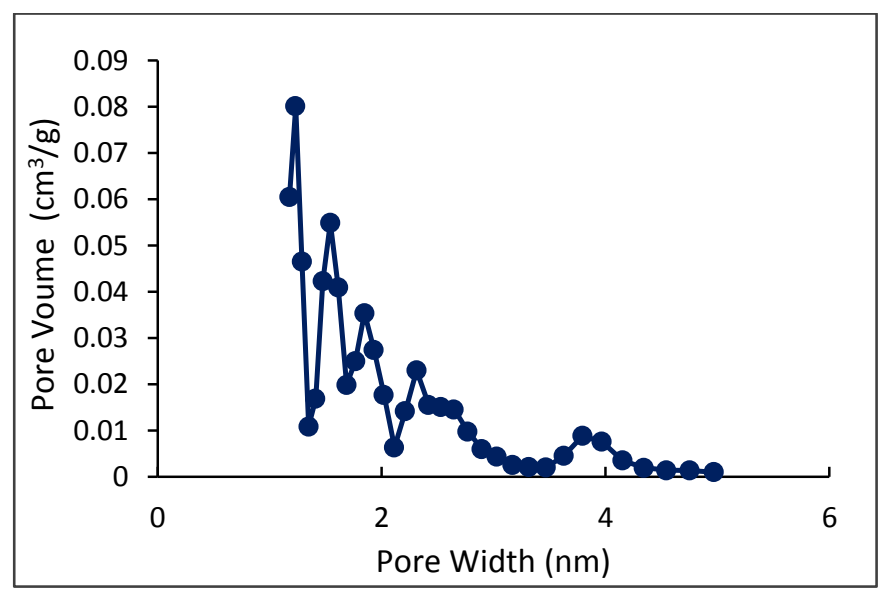

Figure 4. DFT pore size distribution of activated carbon at optimum conditions 


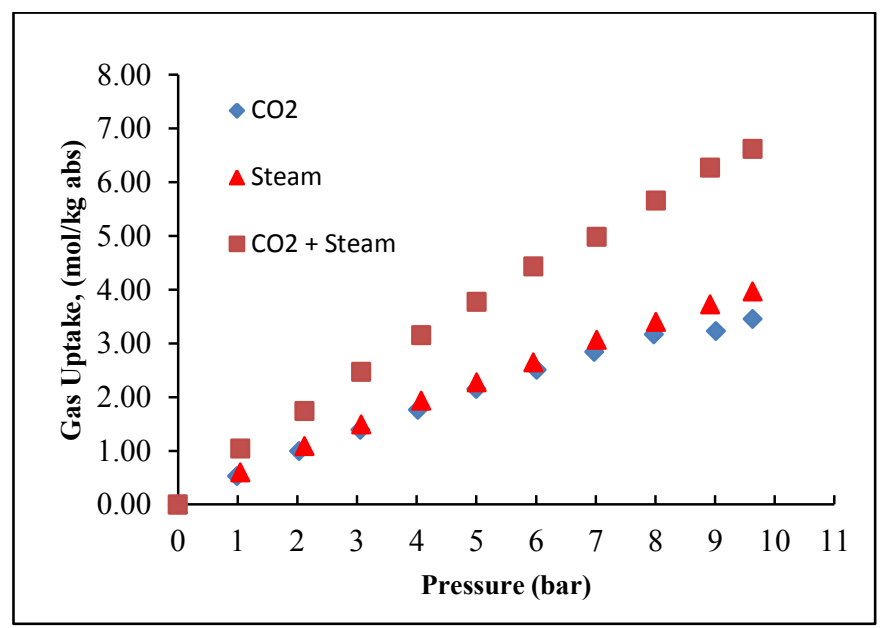

Figure 5. Methane uptake of activated carbons prepared at different conditions.

Table 2. Characteristics of porosity of activated carbons

\begin{tabular}{lcccccc}
\hline Sample & $\begin{array}{c}\mathbf{S B E T} \\
\left(\mathbf{m}^{2} / \mathbf{g}\right)\end{array}$ & $\begin{array}{c}\mathbf{V}_{\text {total }} \\
\left(\mathbf{c m}^{3} / \mathbf{g}\right)\end{array}$ & $\begin{array}{c}\mathbf{V}_{\text {Microporous }} \\
(\mathbf{c m} / \mathbf{g})\end{array}$ & $\begin{array}{c}\text { Microporous } \\
\mathbf{( \% )}\end{array}$ & $\begin{array}{c}\mathbf{V}_{\text {Mesoporous }} \\
(\mathbf{c m} / \mathbf{g})\end{array}$ & $\begin{array}{c}\text { Mesoporous } \\
(\mathbf{\%})\end{array}$ \\
\hline $\mathrm{CO}_{2}+$ Steam & 1548.0 & 1.000 & 0.580 & 58.00 & 0.420 & 42.00 \\
Steam & 798.2 & 0.459 & 0.449 & 97.99 & 0.009 & 2.01 \\
$\mathrm{CO}_{2}$ & 787.0 & 0.435 & 0.359 & 82.46 & 0.076 & 17.54 \\
\hline
\end{tabular}

It is widely known that steam is more reactive than $\mathrm{CO}_{2}$. According to thermochemical dissociation of water and carbon dioxide, the hydrogen-oxygen bond of water molecule is relatively easier to break compared to the carbon-oxygen bond, explaining the higher reactivity of steam than $\mathrm{CO}_{2}[11,16]$. Nevertheless, with suitable total pore size distribution, the pore wall of the activated carbon provides relatively strong attractive forces to the surrounding gas molecules. The energy of gas molecules slowly lowered as it passes through narrow space. As a result, gas molecules are packed densely within pore networks of the carbon [17]. Since the diameter size of methane gas is about $0.4 \mathrm{~nm}$ [18], thus to obtain the highest gas adsorption, the pore size of activated carbon must be bigger than the size of two molecules of methane $(0.8 \mathrm{~nm})$ [19]. Less methane adsorption capacity is expected when activated carbon has low surface area, low volume and has very large pore size diameter.

Thus, in this study, the average pore size diameter, total pore volume and surface area can be regarded as suitable dimension for methane gas adsorption. Therefore, high capacity of methane gas is favourably adsorbed into activated carbon. Similar results were reported by Daud et al. [20], and Azevedo et al. [21], on the porosity development.

Simultaneously, the methane uptake was analysed in term of volume basis. The volume of activated carbon is determined by compressing a known amount of activated carbon at 200 bar. The highest methane uptake of the three activated carbons are shown in Figure 6. The methane storage was measured at $293.15 \mathrm{~K}$ and $10 \mathrm{bar}$. As can be seen in the Figure 5, the activated carbon prepared using combination of $\mathrm{CO}_{2}+$ steam activation agent recorded the highest storage of $145.89 \mathrm{~V} / \mathrm{V}$ compared to other mode of activation. According US Department of Energy, the practical storage capacity for gas-powered vehicles is $180 \mathrm{~V} / \mathrm{V}$ at $35 \mathrm{bar}$ [21]. Thus it can be concluded that, the methane uptake of activated carbon prepared under sequential combination of $\mathrm{CO}_{2}+$ steam activation agent nearly achieved the desired storage capacity for vehicle application. 


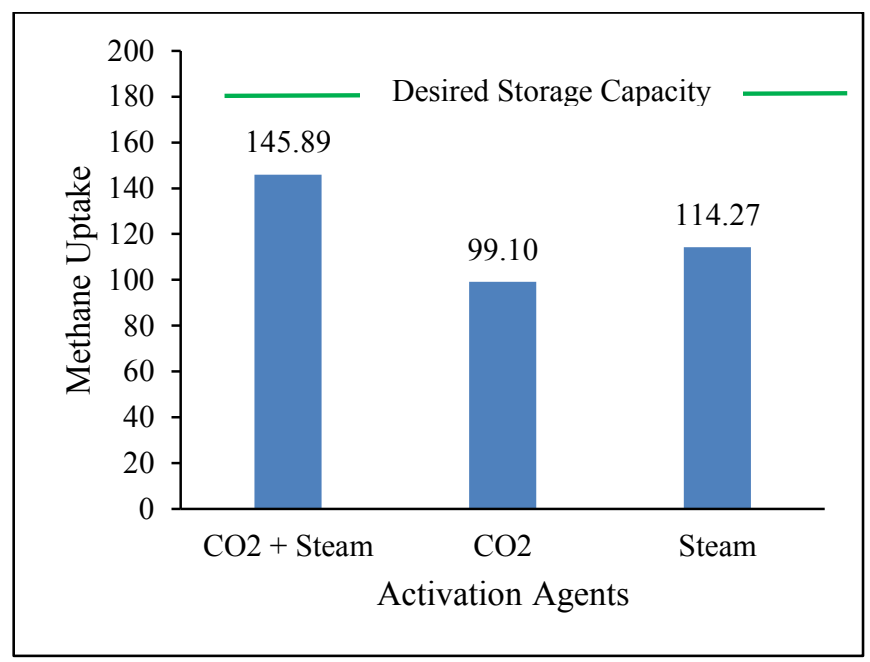

Figure 6. Methane Uptake in volumetric based

\section{Conclusion}

Palm kernel shell is regarded as suitable precursors for production of activated carbon. The activation with $\mathrm{ZnCl}_{2}$ under combination in sequence of $\mathrm{CO}_{2}$ and followed by physical activation proved to be an efficient method in production of activated carbon for methane adsorption. This preparation method leads to high BET surface area $\left(1548.00 \mathrm{~m}^{2} / \mathrm{g}\right)$ and high pore volume $\left(1.00 \mathrm{~cm}^{3} / \mathrm{g}\right)$ with proper dimension of pore size distribution $(1-3 \mathrm{~nm})$. The sequential combination of $\mathrm{CO}_{2}$ and steam is a good combination since $\mathrm{CO}_{2}$ tends to open the outer structure of activated carbon allowing steam with higher rate of reaction strike deep inside activated carbon to develop more pore volume. Methane adsorption capacities of various activated carbons prepared at combination of activation agent and single activation agent were determined at $293.15 \mathrm{~K}$ and 10 bar on mass basis as well as on the volume basis. Among the three different activated carbons, the higher methane uptake on the mass and volume basis was found in activated carbon prepared under combination of activation agent owing to its high surface area, and large total pore volume.

\section{Acknowledgment}

This study was financially supported by the Ministry of Higher Education (MoHE) via the Fundamental Research Grant Scheme (project no: FRGS/1/2013/TK07/UiTM/02/2). Mohd Saufi Md Zaini is thankful to UiTM and MoHE for the scholarship award.

\section{References}

1. Solar, C., Blanco, A. G., Vallone, A. and Sapag, K. (2010). Adsorption of methane in porous materials as the basis for the storage of natural gas. Natural Gas: pp. 205.

2. Arami-Niya, A., Daud, W. M. A. W. and Mjalli, F. S. (2010). Using granular activated carbon prepared from oil palm shell by $\mathrm{ZnCl}_{2}$ and physical activation for methane adsorption. Journal of Analytical and Applied Pyrolysis, 89: 197 - 203.

3. Najibi, H., Chapoy, A. and Tohidi, B. (2008). Methane/natural gas storage and delivered capacity for activated carbons in dry and wet conditions. Fuel, 87(1): $7-13$.

4. Ahmadpour, A., Okhovat, A. and Mahboub, M. D. (2013). Pore size distribution analysis of activated carbons prepared from coconut shell using methane adsorption data. Journal of Physics and Chemistry of Solids, 74(6): $886-891$.

5. Molina-Sabio, M., Gonzalez, M. T., Rodriguez-Reinoso, F. and Sepúlveda-Escribano, A. (1996). Effect of steam and carbon dioxide activation in the micropore size distribution of activated carbon. Carbon, 34(4): $505-509$.

6. Rodriguez-Reinoso, F. and Molina-Sabio, M. (1992). Activated carbons from lignocellulosic materials by chemical and/or physical activation: an overview. Carbon, 30(7): $1111-1118$. 
7. Minkova, V., Marinov, S. P., Zanzi, R., Björnbom, E., Budinova, T., Stefanova, M. and Lakov, L. (2000). Thermochemical treatment of biomass in a flow of steam or in a mixture of steam and carbon dioxide. Fuel Processing Technology, 62(1): 45 - 52.

8. Carrott, P. J. M., Carrott, M. R., Guerrero, C. I. and Delgado, L. A. (2008). Reactivity and porosity development during pyrolysis and physical activation in $\mathrm{CO}_{2}$ or steam of kraft and hydrolytic lignins. Journal of Analytical and Applied Pyrolysis, 82(2): 264 - 271.

9. Manocha, S. M. (2003). Porous Carbon. Department of Materials Science, Sandar Patel Univeristy, India.

10. Herawan, S. G., Hadi, M. S., Ayob, M. R. and Putra, A. (2013). Characterization of activated carbons from oil-palm shell by $\mathrm{CO}_{2}$ activation with no holding carbonization temperature. The Scientific World Journal, 2013: $1-7$.

11. Rodriguez-Reinoso, F., Martin-Martinez, J. M., Prado-Burguete, C. and McEnaney, B. (1987). A standard adsorption isotherm for the characterization of activated carbons. Journal of Physical Chemistry, 91: 515 516.

12. Rouquerol, J., Rouquerol, F., Llewellyn, P., Maurin, G. and Sing, K. S. (2013). Adsorption by powders and porous solids: principles, methodology and applications. 2nd ed. London: Academic Press Inc.(London) Ltd.

13. Kundu, A., Gupta, B. S., Hashim, M. A. and Redzwan, G. (2015). Taguchi optimization approach for production of activated carbon from phosphoric acid impregnated palm kernel shell by microwave heating. Journal of Cleaner Production, 105: 420 - 427.

14. Guo, J. and Lua, A. C. (2000). Textural characterization of activated carbons prepared from oil-palm stones pre-treated with various impregnating agents. Journal of Porous Materials, 7(4): $491-497$.

15. Arami-Niya, A., Daud, W. M. A. W. and Mjalli, F. S. (2011). Comparative study of the textural characteristics of oil palm shell activated carbon produced by chemical and physical activation for methane adsorption. Chemical Engineering Research and Design, 89(6): 657 - 664.

16. González, J. F., Encinar, J. M., González-García, C. M., Sabio, E., Ramiro, A., Canito, J. L. and Gañán, J. (2006). Preparation of activated carbons from used tyres by gasification with steam and carbon dioxide. Applied Surface Science, 252(17): 5999 - 6004.

17. Prasetyo, I., Yunanto, R., \& Ariyanto, T. (2011). Methane storage by methane hydrate formation within water-saturatedporous carbon: The effect of mesoporosity. Chemical Engineering Department, Gadjah Mada University, Indonesia.

18. Mosher, K. (2011). The impact of pore size on methane and $\mathrm{CO}_{2}$ adsorption in carbon. Stanford University, United Kingdom.

19. Almansa, C., Molina-Sabio, M. and Rodríguez-Reinoso, F. (2004). Adsorption of methane into $\mathrm{ZnCl}_{2}$ activated carbon derived discs. Microporous and Mesoporous Materials, 76(1): $185-191$.

20. Daud, W., Ashri, W. M., Ali, W. S. W. and Sulaiman, M. Z. (2003). Effect of activation temperature on pore development in activated carbon produced from palm shell. Journal of Chemical Technology and Biotechnology, 78(1): $1-5$.

21. Azevedo, D. C., Araujo, J. C. S., Bastos-Neto, M., Torres, A. E. B., Jaguaribe, E. F. and Cavalcante, C. L. (2007). Microporous activated carbon prepared from coconut shells using chemical activation with zinc chloride. Microporous and Mesoporous Materials, 100(1): 361 - 364. 